Revista Iberoamericana, Vol. LXX, Núm. 206, Enero-Marzo 2004, 237-249

\section{VISIONES DISCURSIVAS A PARTIR DE LA APARICIÓN DE UN CANON ALTERNATIVO: CLARICE LISPECTOR, DIAMELA ELTIT Y EUGENIA GALLARDO Y EL CÓMO NARRAR DESDE ESPACIOS FEMENINOS}

\author{
POR
}

Aída Toledo

The University of Alabama

El canon literario ha sido el repertorio de obras consideradas apropiadas para conservar, estudiar y difundir en determinada sociedad los valores históricos y sociales de una nación y se compone de obras institucionalizadas y representativas de la producción literaria central o hegemónica, la crisis respecto al canon literario en las últimas décadas ha puesto en evidencia las luchas internas, ideológicas, que subyacen en todo proceso de canonización. El canon de la literatura latinoamericana entró en un proceso de revisión y renovación mediante la incorporación de literatura previamente excluida o de obras de los nuevos escritores, proceso que estaba en relación con la necesidad de revalorización de las nuevas generaciones críticas cuya formación estaba más en consonancia con los cambios en el concepto de literatura, la aparición de literaturas emergentes, ${ }^{1}$ y la velocidad con que la información y las renovadas formas de acceso a los libros y bibliotecas se había hecho posible. La renovación se ha extendido a la literatura de grupos marginados, pero quizás haya sido el feminismo el que particularmente logró la representación de más escritoras dentro del canon en ese entonces. Para 1988 Beatriz Pastor afirmaba que el canon estaba de moda como tema polémico dentro de la academia, como parte de un trabajo de revisión en el que la crítica latinoamericana se veía necesitada de participar. La historia de la polémica sobre el canon de la literatura latinoamericana encuentra en la percepción de Beatriz Pastor una forma de explicarse por qué su redefinición posee implicaciones que rebasan el marco de la discusión intelectual o académica. Porque para esta crítica la polémica sobre el canon es una manifestación que implica sobre todo un cuestionamiento del estatuto del campo de las humanidades en general. ${ }^{2}$

En la historiografía de América Latina es posible situar cuatro momentos de canonización, el de la élite romántica, el de la élite regionalista, el del medio siglo, y el que se inicia a partir de los años ochenta, correspondientes a los procesos de reafirmación nacional, americanista, época de la nueva novela y Boom, y época del Post-Boom.

\footnotetext{
${ }^{1}$ Aquí se habla de literaturas emergentes como el llamado "testimonio" que representa el momento en que grupos marginados y carentes de poder entran al canon con sus obras testimoniales.

${ }^{2}$ La pregunta está centrada en lo que significan las humanidades, si su existencia perpetúa una concepción del mundo y de la historia de carácter eurocéntrico y ligada a los procesos imperialistas en los que se ha formado, o si la visión por el contrario va a poder abrirse a una pluralidad de visiones, convirtiéndose en un humanismo que trabaje dentro de las expectativas de raza, sexo, clase o cultura.
} 
Si durante el siglo xIX se canonizaron las novelas que afirmaban lo nacional, durante las primeras décadas del xx entraron a figurar las que ofrecían una definición cultural y sobre todo una reafirmación latinoamericana como Doña Bárbara, La vorágine y Don Segundo Sombra. Al mismo tiempo surgieron de las vanguardias escritores como Mário de Andrade con una obra como Macunaíma (1928), el Miguel Angel Asturias de Leyendas de Guatemala (1930) y Alejo Carpentier con Ecue-Yamba-O (1933), dentro de registros narrativos distintos. Las diferentes tendencias narrativas se desarrollaron simultáneamente y hacia los años cuarenta el trabajo sobre la renovación de la novela latinoamericana en las distintas vertientes buscaría un reconocimiento mundial cuyos parámetros estarían regidos por el éxito editorial, los premios literarios, las traducciones y la consagración obtenida en el extranjero. Durante este período, matizado principalmente por los conflictos políticos internos en toda Latinoamérica, la narrativa se mantendría en la línea temática ligada a éstos. No será sino en los años sesenta cuando aparecerán los escritores del Boom, Gabriel García Márquez, Julio Cortázar, Carlos Fuentes, Mario Vargas Llosa y otros, cuando el registro narrativo emprende la asimilación -y, poco después, disolución de todas las tendencias anteriores.

Durante las dos últimas décadas del siglo xx una serie de libros que hasta el momento estaban considerados como subliteratura o literatura menor, hacen su entrada en los espacios literarios y aparecen desarticulando el discurso hegemónico. ${ }^{3}$ Entre estos nuevos géneros tienen especial importancia las distintas variantes del testimonio. Lo mismo sucedió al nuevo auge y perspectiva teórica de los estudios coloniales y a la literatura escrita por mujeres. De esta forma, y determinados por las crecientes presiones políticas, económicas y culturales, los cánones han debido abrirse y ser más flexibles, asimilando las nuevas tendencias, tomando ahora sí como punto central la heterogeneidad de la cultura latinoamericana.

Una revisión actual de los componentes del canon latinoamericano, pone en evidencia entonces que la mayoría de autores de la primera mitad del siglo xx se mantuvieron dentro de registros narrativos cuyas tendencias fueron la novela de la tierra y el realismo social o incluso socialista. La tendencia experimental y ecléctica desarrollada por los vanguardistas de la década del veinte es fácilmente rastreable a partir de los años cincuenta, y sus texturas y matices corresponden a otra sensibilidad cuyo contexto parece ser el posmoderno. Es aquí en donde inserto las voces de escritoras como Clarice Lispector, Diamela Eltit y Eugenia Gallardo.

Clarice Lispector es una de las primeras en iniciar el trabajo del desplazamiento del sujeto dentro de una perspectiva feminista. Sus personajes, en la mayoría mujeres, van perfilándose dentro de mundos que las distinguen por su capacidad de observación y análisis. El conocimiento filosófico de Lispector entra en la conformación de estos personajes que suelen exhibir a través del fluir de conciencia las preocupaciones de sujetos femeninos y enmarcar las diferencias entre la realidad que las circunda y el discurso que las produce.

\footnotetext{
${ }^{3}$ Tanto Hugo Achugar como John Beverley coinciden en señalar lo complejo y heterogéneo de la
} literatura del testimonio, en La voz del otro: testimonio, subalternidad y verdad narrativa. 
La obra de Lispector al hablar de la condición de la mujer y al inscribirla como el sujeto de la historia de la narración, dentro de la Historia con mayúsculas, no se limita a una postura representacional de reflejar tal o cual mundo patriarcal y denunciarlo como lo hicieron los naturalistas, sino que va construyendo un campo de meditación y de mediación en el que profundiza las relaciones entre literatura y realidad (Helena 109).

Una lectura acuciosa de la última obra de Lispector, $A$ hora da estrela revela que se incluye en uno de los proyectos fundamentales de la novela brasileña en la década del setenta, o sea la ficción próxima a la tradición realista, con el debido lastre de lo documental y la tendencia alegórica; y sin embargo el principio de construcción que aleja a Clarice de esa tradición es la complejidad de sus personajes, porque su propuesta conlleva un nuevo metabolismo de esos elementos. La novela y su configuración de lo femenino, ocupan un espacio fantasmagórico en el que intervienen las fantasías captadas del imaginario cultural de los hombres sobre las mujeres, de los hombres sobre sí mismos y a la inversa, pero todo como una representación del imaginario patriarcal.

Las continuas transgresiones de Clarice durante el proceso de la escritura, esa utilización del imaginario masculino para construir al personaje de la ficción del narrador, provocan la parodización del acto creador. ¿Desde dónde narrar? ¿Cuál es la perspectiva? En un desdoblamiento continuo en donde lo que se busca es crear el absurdo para subvertir el orden, el narrador, un escritor marginal que se encuentra en el proceso de la escritura, acierta a encontrarse a sí mismo a través de los mecanismos de configuración de su propio personaje. Existe un elemento lúdico que hace ambigua la serie de interpretaciones posibles. Lleno de alusiones de tipo mordaz -el imaginario masculino- el narrador acomete contra su personaje central, Macabéa, la nordestina pobre, fea y desnutrida. Pero sin embargo, a través de esa conducta, el narrador es parodizado por Lispector. En él se resume la carga crítica y se parodizan además las estructuras literarias de la tradición patriarcal. El libro se encuentra cargado de esta actitud del narrador, ya que Clarice pone en sus palabras toda la fatuidad de dicho imaginario. Los grandes temas como la incomunicabilidad, la estética de lo feo y de lo bello, el silencio y la definición del ser, son trabajados por Clarice de un modo hasta jocoso. En los silencios de Macabéa, la escritora de $A$ hora da estrela enfatiza en dos principios que perviven en sus personajes femeninos y que se constituyen en estrategias de resistencia escritural, el silencio y la infinitud; y para Pierrette Malcuzynski, en este sentido, Lispector está constantemente creando un espacio discursivo estratégico de resistencia pero a través de la técnica de la parodia (130). Vilma Arêas observa que en esta obra se produce un juego escénico en donde se utilizan máscaras y muecas, improvisación, delirio verbal, material remendado; Lispector parece estar utilizando una inversión de los roles constructivos, es el lenguaje figurado quien inventa el nivel de lo real; el juego de las voces narrativas entremezclándose, pero al mismo tiempo guardando una distancia estratégica para que podamos diferenciarlas y captar el sentido de lo que se narra en un patente desplazamiento de tonalidades, éste es otro de los ardides constructivos de Clarice. Y si lo que se narra, como lo explica Arêas, es la historia de la pobreza, al mismo tiempo se pone en evidencia la difícil relación del intelectual con ese tema. A través de las actitudes del narrador Lispector parodia esa relación, ya que para ella hay una distancia perceptible en la diferencia de clases sociales, una irreductibilidad de clases; de esta certeza puede provenir el desdoblamiento del autor en un narrador que a su 
vez crea los personajes de la ficción enfrente del lector. Se denuncia la distancia en este artificio y como observamos en la actitud de Rodrigo S.M., la fatuidad y el rechazo hacia Macabéa y ese nivel de odio-amor que maneja en la construcción de su personaje, produce el efecto paródico totalizante que la crítica ha observado en esta corta narrativa de Lispector.

Kiremidjian, citado por Elzbieta Slodowska, dice que la parodia representa un modo particular del estado del arte cuando ese arte se vuelve sobre sí mismo, cuando se vuelve introvertido e introspectivo, curioso con respecto a su propio ser, explotando su propia forma con el propósito de autoconocimiento, menos interesado en reflejar las realidades metafísicas que en articular procesos epistemológicos (Sklodowska 11). A hora da estrela significa dentro del contexto latinoamericano esa obra en la cual la autora, repensando sus posturas estéticas, la organiza para dialogar con otros textos narrativos de su propia tradición y se inserta en un circuito marginal en el caso específico de ella, en la escritura elaborada por mujeres en el contexto latinoamericano, y en una realidad social, la del noreste del Brasil. ¿En qué medida Lispector está parodiando esa realidad social y esa realidad escritural? Lo hace consciente de que los procesos de escritura están determinados por la tradición; quizás por eso la estructura del libro deviene una manera de repensar e ironizar sobre el acto de escribir. Y así comenta el personaje:

Relato antigo, este, pois não quero ser modernoso e inventar modismos à guisa de originalidade. Assim é que experimentarei contra os meus hábitos uma historia com começo, meio e "gran finale” seguido de silêncio e de chuva caindo. (Lispector 27)

La distancia irónica con que Clarice trabaja este libro hace indispensables los recursos intertextuales que según Hutcheon, apoyada en las ideas de intertextualidad de Julia Kristeva, aparecen en textos de este calibre cuando hay una intención paródica; ${ }^{4}$ en A hora da estrela se dan entremezclados, son parte de una tradición de escritura en donde los tópicos han ido pasando de una generación a otra. Elzbieta Sklodowska ha observado que cuando la parodia asume cierto estatus marginal -en este caso la obra es escrita por una mujer, emplazando el sistema de escritura masculino-se pone de relieve el mecanismo de la carnavalización (xvi); la actitud insistentemente contradictoria del narrador provoca en el discurso una intensidad lúdica que inicia la curva paródica, llevando a excesos cuestiones particulares de esta nueva narrativa de la posmodernidad como pueden ser las dimensiones metaliterarias: autoconciencia, autorreflexión, autorreferencialidad, etc. Los personajes son conducidos a extremos porque Lispector persiste en el tratamiento paródico de lo paródico, en la confección de Macabéa, Clarice Lispector altera el discurso original por medios paródicos y provoca un cambio significativo en el campo semántico.

Las estrategias intertextuales le van sirviendo a la autora brasileña en diversos sentidos; no sólo permiten contar desde dentro hacia afuera, sino que también revelan en el nivel de lo social, la naturaleza de los componentes del contexto. Esta nueva novela de la posmodernidad escrita por mujeres dentro de la carnavalización, es un proyecto reivindicador-subversivo de la escritura femenina en cuanto enfrentamiento polémico de

${ }^{4}$ Hutcheon citada por Sklodowska, La parodia en la nueva novela..., 12. 
frente al discurso masculino, situándose de esta forma en una última de las categorizaciones paródicas porque presupone un diálogo crítico con lo que se llama "discurso usurpado" (Sklodowska 146), en donde la competencia del lector es fundamental para la percepción de la obra, ya que tiene que descifrar el texto a la luz de otros textos, recurriendo en esta tarea a su competencia intertextual. Pareciera ser un libro que alcanza mucho más sentido crítico en el contexto de los últimos años del siglo xx dentro de la corriente del feminismo latinoamericano de fin de siglo.

Diamela Eltit (1949) es al momento de la escritura de este trabajo una de las escritoras latinoamericanas que, después de Clarice Lispector, más ha retrabajado y reproblematizado las maneras de narrar vigentes, provenientes de una visión patriarcal, masculinizante y mestizante. Sus novelas representan en la actualidad una novedosa manera de enfrentar el hecho narrativo, ya que desde el lenguaje transgrede el estilo “culto” de una tradición que tiene su mejor momento durante el período del Boom y que mantiene una línea invisible e irrompible en la narrativa reciente de escritores como José Donoso, Tomás Eloy Martínez y Antonio Skármeta, para citar sólo algunos nombres.

Eltit inicia su trabajo narrativo con la novela Lumpérica (1983), planteando desde allí una problemática que, según ella, aunque se encuentra ligada a la mujer como sujeto histórico, no necesariamente representa una visión feminista o de género.

Sin embargo, leer a Diamela Eltit en cualquiera de sus textos narrativos, significa entrar abruptamente a distintas reflexiones sobre la problemática de la mujer, su papel dentro de la sociedad latinoamericana, la subordinación a nivel familiar y las instancias que todo aquello implica. Raquel Olea ha escrito un ilustrativo trabajo acerca de cómo funcionan en la narrativa de la escritora chilena el sexo y el género, los cuales según esta crítica se han configurado en el imaginario cultural como una analogía de identidad, cuyo cuestionamiento significa una amenaza a las identidades definidas principalmente por su función en la reproducción de la especie (Olea 87). Así, en la narrativa de Eltit, hay múltiples hilos por donde armar metáforas de las simbólicas de lo femenino y lo masculino como polaridades opuestas: las oposiciones público/privado, cultura/naturaleza, activo/ pasivo, razón/intuición, escritura/oralidad, centro/periferia, etc. Según Olea, Eltit construye una máxima productividad del cuerpo como depósito de experiencias que explícitamente proponen identidades que, o bien incluyen acumulativamente experiencias pre-signadas, o bien generan otras (Olea 88). Según Nelly Richard la literatura de Diamela Eltit se fundamenta en la construcción de cuerpos como espacios físicos señalados por su sumisión o resistencia a los poderes sociales e individuales que los articulan: la costumbre, la ley o los sistemas de normas morales (90). En torno a su novela Los vigilantes, la autora chilena ha afirmado que esos cuerpos que ella construye no son los mismos que construyó el Boom, sino que son cuerpos más pequeños, cuerpos fallados que caben en microespacios (Morales 83). Lo femenino es representado en la narrativa de Eltit desde su carácter residual, pre-codificado, de economía inversa; desde allí asume su propia diferencia señalada por su no-lugar entre los códigos neutralizadores. Es un contradiscurso, su representación una sustracción, de esta forma funde lo íntimo hecho público y político (Ortega 76).

En el análisis que Silvia Tafra hace sobre la narrativa de esta escritora, encuentra que en sus novelas el erotismo traspasa los cuerpos, especialmente el cuerpo de la mujer, que 
es el cuerpo mismo del texto (41-2). Acerca de esto Diamela Eltit ha dicho que siempre ha trabajado cuerpos en crisis. Y desde un punto de vista más conceptual, el cuerpo es un material literario que le parece estratégico, que todavía no termina de agotar (Morales 83).

Leonidas Morales ha señalado que uno de los mayores intereses de Eltit está en esos cuerpos femeninos que se transforman en sus obras en escenarios rituales. La fisonomía de esos cuerpos va transformándose y devienen, además de cuerpos sexuales, en cuerpos sociales y populares, en suma objetos de represión política (81). De esta manera también la crítica literaria ha leído estas obras de la autora chilena como parte de un proyecto antidictatorial, porque la escritura de éstas ha sido precisamente dentro del período autoritario más álgido, durante las distintas fases de posicionamientos políticos por las que el gobierno militar transitó desde 1983, fecha en que se publicó Lumpérica, hasta fines de 1988, año de la publicación de El cuarto mundo. Respecto a escrituras como ésta, José Joaquín Brunner ha escrito que el cruce de relaciones se torna más problemático y significativo al momento de caracterizar la producción artística de este período, pues el régimen militar constituyó un quiebre profundo en todo el tejido social y en el sistema de representaciones simbólicas (Brunner 69). Algunas de las consecuencias fueron la polarización de las prácticas artísticas en dos bandos antagónicos: el oficialista y el no oficialista, la censura como amenaza externa y su versión interna, la autocensura.Todo esto se constituyó en un instrumento de poder muy eficaz para silenciar y amedrentar la producción cultural.

La crítica eltitiana ha observado acertadamente cómo las ciudades en la narrativa de Diamela Eltit son espacios sitiados, espacios tomados, y por ende fragmentados, estrategia narrativa que la autora chilena utilizará como alegorización de esa construcción en Los vigilantes (1994) que se estructura principalmente a través del uso de la fragmentación en los distintos niveles del discurso y de los significados. En esta corta narrativa Eltit cuestiona y discute, a veces con algunos de sus propios libros anteriores, temas como la dependencia, el poder centralizado y sus operativos de represión; la ciudad como un lugar cercado y tomado; el ciudadano como un ente subsumido en el olvido, degradado y acosado por esos poderes. No es extraño que al mismo tiempo que escribe esta novela, la autora estuviera trabajando otros textos alusivos a fotos del hospital psiquiátrico de Putaendo. Este otro libro se titula El infarto del alma, que logra mantener relaciones intextextuales con su novela del 94. En la misma entrevista con Leonidas Morales comentada anteriormente, Eltit narra las relaciones intertextuales entre los dos libros, ya que para ella algunas de las estrategias discursivas en Los vigilantes, provienen de las que desarrolló en la creación de los poemas en prosa insertos junto a las fotos (Morales 17677). Además el trabajo de la ciudad en Los vigilantes está en relación directa de imagen urbana con los espacios abierto-cerrados del hospital de Putaendo. Observando las fotos de El infarto del alma y leyendo simultáneamente Los vigilantes se percibe cómo los desamparados vienen a ser en imagen los reclusos de Putaendo y cómo los espacios ciudadanos que ocupan, esas orillas, esos edificios públicos, son una alegoría del hospital psiquiátrico. Una de las imágenes que más la impacta en el hospital viene a ser la del hambre, que en la novela se transforma en deseo y tiene correspondencia con la forma en que los reclusos del hospital suelen hacer pactos de amor, de convivencia, dentro de esas paredes. En Los vigilantes, los desamparados vienen a ser una imagen en espejo de los 
reclusos. Eltit guarda en sus descripciones posiblemente el fuerte estado emotivo que la embargaba al momento de estar en el hospital, y las historias se entrecruzan; uno y otro libro se hacen préstamos, si no textuales exactamente, sí de las descripciones y los estados anímicos. La relación se hace todavía más evidente si revisamos las estrategias discursivas, ya que en el libro de Putaendo Eltit está usando la técnica de la carta tal y como logra estructurar la segunda parte de Los vigilantes. Lo intertextual es entonces, un aspecto muy fuerte en esta obra de la escritora chilena. Ella misma relata que cuando escribía la novela del 94 estaba pensando en Faulkner y en Beckett. Los referentes literarios del niño vienen a ser Molloy de Beckett y su lectura de El sonido y la furia de Faulkner (Morales 45). Además, el tratamiento del poder era algo que le interesaba muchísimo. Otro de los datos interesantes proporcionados por Eltit es que cuando pensaba en la novela, lo hacía políticamente en términos de liberar la diferencia de escritura, la diferencia del sujeto, los órdenes, los lugares sociales, los roles. Quería pasar por varios niveles y llegar sobre todo a la experiencia de la escritura como riesgo y como desalojo. En la madre que es quien escribe las cartas a un pretendido interlocutor, Eltit reproblematiza el poder en relación a la escritura porque este personaje ya no puede habitar los centros; se encuentra en ese centro, para ella entre comillas, pero desalojada por su diferencia. Y así en la medida que no hace pactos, que no obedece pactos sociales, tiene que quedar afuera (Morales 49). Las identidades se construyen mediante estrategias de distorsión y ambigüedad. No existen concesiones ni momentos de tranquilidad operativa. La tensión de la narración mantiene un mismo nivel que a momentos se entronca con la locura. Así es que por medio de las estrategias de confección de los personajes que se encuentran desdibujados por la oblicuidad de sus focalizaciones Eltit crea un clima de desinformación y divagación que atraviesa la novela. La madre perderá el poder de la escritura y esto la coloca en una posición de dependencia respecto al niño, que antes de ese momento dependía de ella para todo, inclusive para caminar. Y hay cierta predestinación en esta solución que Eltit escoge para su personaje femenino, ya que queda expuesta a la fuerza que la larva, esa criatura, tiene sobre ella que ha perdido el poder que la escritura le daba. Una parte de la estrategias textuales de Eltit está en la tensión que provoca entre los personajes al invertir las posiciones. Hay en la historia una reflexión acerca del fracaso, cuando el niño proclama: “Ahora yo domino esta historia” (126). Al final, Eltit parece estar regresando a los orígenes. Elabora una alegoría de subsistencia a través de los instintos: los perros aullando hacia la luna como un símbolo.

Eugenia Gallardo (1953-) publica su primer libro de narraciones, No te apresures en llegar a la Torre de Londres, porque la Torre D Londres no es el Big Ben en 1999. Es un ejemplo típico, a primera vista, de la literatura del exilio cuyos registros reflejan las preocupaciones íntimas de una sociedad silenciada y reprimida cuyos componentes habitan simbólicamente en espacios cerrados o en las afueras del límite de lo nacional. El libro se estructura como un calendario de 52 semanas con una narración por semana, ejemplificando una vez más cómo muchas narraciones elaboradas por mujeres latinoamericanas presentan características similares en cuanto a su naturaleza híbrida y la necesidad de negar “lo racional” masculino dentro de la lógica tanto de composición como de narración. 
Formalmente los textos son unidades fragmentadas, cuyos vínculos de unión se elaboran como en las historias de la picaresca. ${ }^{5}$ Cada principio y final deja una incógnita: hay un pregunta elaborada o dejada a la casualidad que se recoge en el capítulo textual siguiente. El libro se encuentra dividido en 53 textos ya que existe un epílogo final, en donde se deja una última pregunta por contestar. Con esta estructura Gallardo se plantea la escritura de una autobiografía atípica a la cual se le ha llamado "proyecto de errática escritura intimista” (Méndez 27-33). Los elementos tomados de la vida de la autora son múltiples pero Gallardo lleva esta información hacia estados ficcionales que le permiten evadir o contradecir el carácter de sí histórico del género autobiográfico. ${ }^{6}$ El primer texto introduce al lector en una de las preocupaciones de la autora mediante elementos paródicos e inclusive a niveles de lo cursi y gastado, como herramientas con las que intenta emplazar y trastocar los modelos masculinos. ${ }^{7}$ La referencia es a las historias contadas en la infancia, patrones sociales y familiares dificilmente eliminables en la edad adulta. El primer texto es una versión paródica del cuento de la Bella durmiente, quien, en el mundo ficcional de Gallardo, no desea despertar, a pesar de la insistencia del príncipe que inclusive le ofrece no variar su estatus de "bella durmiente" si ella accede: "Despierta, mi dulce amada. No temas, seguirás llamándote La Bella Durmiente, pero despierta. La princesa no respondía. La princesa no respondía porque soñaba” (Gallardo 7). Esta historia le sirve a Gallardo para emplazar los esquemas del patriarcado; ${ }^{8}$ usando escenas típicas de los relatos contados a los niños, elabora una lectura en múltiples sentidos. ${ }^{9}$ El tema de emplazamiento a las formas de conducta de los personajes dentro de un esquema social machista se mantiene en el resto de los textos. No existen hilos conductores o tramáticos tradicionales; una de las excéntricas formas de enlazar los relatos es un hilo temático, invisible y

\footnotetext{
${ }^{5}$ Según Edward Friedman existe una vinculación entre la picarezca como género y la autobiografía, una conciencia inevitable del acto creativo y del material recreado. Otros rasgos serían el rol marginal del personaje, la conciencia social tanto del personaje como del creador, la presencia de la ironía en los niveles de la historia y del discurso narrativo.

${ }^{6}$ A principios del siglo xix, el autor inmune al deseo de reivindicarse ante la historia, entrevé una realidad más compleja subyacente en la tarea autobiográfica, la urgente necesidad de colocar su texto dentro de los límites de la historia, disciplina más segura, coarta toda reflexión sobre las complejidades de la memoria (Molloy 187).

${ }^{7}$ Lo cursi está regularmente ligado a lo telenovelesco y melodramático. En este caso el uso de esos niveles de comunicación tiene una doble intención, relacionada con la desacralización de lo culto masculino, muy respetado por los escritores hombres de los distintos filones de la literatura guatemalteca en sus narrativas, como puede observarse en la producción masculina publicada desde los años setenta hasta el momento actual.

8 "La mujer latinoamericana ha enfrentado una problemática de subordinación durante siglos y una de las consecuencias "literarias" de esta circunstancia es la continua representación de personajes femeninos que juegan el papel de víctimas. Los cuentos de hadas han sido un espacio privilegiado para reforzar esas conductas. Releer y reescribir a la "Cenicienta" o a "Blanca Nieves", sólo por mencionar a dos, se vuelve, a nuestro parecer, un gesto político que se dirige a la historia de la literatura como poder y la narrativa que ha limitado al sujeto femenino en su dimensión física y mental" (Schroeder 13).

${ }^{9}$ Mariana Hirsch observa que la ironía es uno de los rasgos más característicos del bildungsroman
} (67). 
subversivo, que atraviesa todos los textos dándoles unidad, pero dicha unidad funciona independientemente en cada relato para asociarlo con los rasgos de la autobiografía que en el fondo también se está escribiendo. Eugenia Gallardo establece así un pacto lúdico con el lector, desorientándolo con falsas pistas de interpretación (Méndez 1). A la primera narración de este libro se le adicionan referencias a otros cuentos infantiles con personajes femeninos como el de "Blanca Nieves”, pero en el texto de Gallardo se trastoca la historia con las alusiones de cierta intimidad en compañía de los siente hombrecitos; el tono carnavalesco que asume la voz narrativa al hacer la pregunta en boca de otros personajes que están a la espectativa de lo que va a suceder se torna absolutamente paródico e inconcebible ante lo absurdo de la idea: “¿Será que la Bella Durmiente necesita siete príncipes? -interrumpe la mujer. -¡Qué tonterías dices, mujer! ¡qué poco te duró la sensatez! ¿Una princesa con siete príncipes y todos los príncipes felices?” (13). Por otro lado, La Bella Durmiente no despierta de su sueño porque su actividad onírica es mucho más enriquecedora que la oportunidad de iniciar una vida matrimonial que el beso simboliza. El personaje infantil, al no despertar, encuentra en este subterfugio la posibilidad de conocimiento a través del sueño. En la defensa de este recurso, Gallardo testimonia uno de los motores de arranque narrativo más utilizados por las escritoras latinoamericanas contemporáneas (García). En el sueño de la princesa, entonces, volvemos a encontrar los elementos de género e identidad que este libro maneja como mensaje central. La narración sigue un decurso a momentos irracional y fantástico que no permite una lectura con hilos conductores visibles y modélicos, ${ }^{10}$ aunque la reflexión implícita sobre identidad y género se sigue desarrollando a lo largo de los restantes capítulos. ${ }^{11} \mathrm{La}$ crítica a la familia como institución del sistema es evidente también, ya que son continuos los mensajes que sobre este tema trabajan las historias infantiles inocentes y “bonitas”. Los elementos contrastantes, resultados de fusionar las épocas en estas narraciones, causan imágenes oníricas que redoblan los sentidos. Las tonalidades paródicas se acusan mucho más en el capítulo donde la escritora va hacia el aparato literario que acompaña la vida de los niños; con textos como el mencionado llevados a la parodia, la autora entresaca una serie de valores familiares y sociales que se filtran en la fantasía infantil formando modelos de conducta irreversibles. Una de las formas en que Gallardo trabaja los elementos de identidad y género es asociando e invirtiendo los roles de los personajes del mundo infantil con los niños y jóvenes contemporáneos que van apareciendo paulatinamente en sus narraciones. Las estrategias discursivas de Gallardo siguen ciertos modelos de inversión de la realidad narrativa; un ejemplo son las omisiones de un período determinado de historia ficcional. De la misma forma hace aparecer sin conección narrativa a otros personajes; en el capítulo 12 es creada Carmela-Carmelo, “a quien le gustaba vestirse

\footnotetext{
${ }^{10}$ Patricia Meyers Spacks, citada por María Inés Lagos, observa cómo la fantasía sustituye a la acción; y define dicha fantasía como "productos de la mente que sirven el propósito de cumplir un deseo", 78-9.

${ }^{11}$ En su trabajo de presentación del libro de Gallardo, Lucrecia Méndez señala que en el capítulo en donde la oruga Betty es uno de los personajes, la autora retrabaja el papel de la mujer en una sociedad hipócrita, cuyo único estímulo de aceptación de las mujeres que han transgredido las reglas sociales y morales que rigen aquella sociedad, es a través del poder político (3).
} 
como hombre para que escucharan lo que tenía que decir”, protagonista de una de las secciones de mayor coherencia narrativa. Carmela es una voz ficcional femenina pero autoritaria que tiene ciertos rasgos picarescos y cuya falta de identidad es una estrategia social porque sabe que asumiendo una identidad masculina podrá manejarse mejor en el mundo de la fantasía en donde se encuentra inmersa. Es Carmela-Carmelo precisamente quien decide ir en pos de la Torre de Londres, y aunque su travesía se convierte en un fracaso, ya que muere durante el viaje sin haber llegado a la Torre, el deseo es el que la lleva hasta Londres. Aquí Gallardo parece inducirnos a reflexionar acerca de la imposibilidad de concreción del deseo femenino si no es a través de otro tipo de aprehensión de la realidad.

En el texto 17 se desarrolla más ampliamente un elemento estructural que se ha venido hilando a lo largo de los primeros 16 textos, para preparar el viaje autobiográfico. Carmela como personaje se rebela contra su creadora (es difícil no pensar en Unamuno o Pirandello -sólo que aquellos autores modernistas no se preocupaban mucho en Niebla o Siete personajes por cuestiones identitarias relacionadas con género o nación), porque otro de los elementos centrales es el emplazamiento al proceso escritural desde la perspectiva del narrador y del lector. Luego de la muerte de este personaje beligerante, la narración intensifica la fragmentación para, nuevamente en el texto 31, volver a aludir al proceso escritural, pero ahora en boca de la narradora que se ha sumergido en la fantasía y en la autobiografía creando elementos paralelos en su desarrollo. En esta parte del libro hay reminiscencias del texto de Lispector en cuanto a las preocupaciones literarias y la composición del relato. En los textos posteriores dicho hilo conductor resulta humanizado: las intervenciones de voces que no son las de la narradora que ha venido cuestionando el proceso, hacen que el tratamiento de la narración devenga en una especie de polifonía paródica: ${ }^{12}$ Detrás de la voz de la narradora parece estar la voz de la autora; en este espacio discursivo los rasgos autobiográficos se hacen mucho más persistentes. Las estrategias autobiográficas en este libro difieren de la autobiografía canónica que pone un énfasis esencial en la validación del relato biográfico a través de los aspectos históricos. El libro de Gallardo hace exactamente lo contrario, trabajando la fragmentación, los anacolutos y toda una serie de elementos dispersos que juntos producen un efecto anestésico y que paradójicamente se constituyen en rasgos centrales de sus narrativas en vez del contenido biográfico. La forma de cerrar la historia la logra Gallardo induciendo al desciframiento que parece otro rasgo escritural de su narración. Cada una de las cinco imágenes que la narradora va a descifrar o descodificar en busca de respuestas a las adivinanzas del viaje emprendido a partir del texto 48, devienen imágenes visionarias, cuerpos textuales ambiguos y resistentes a la interpretación, que ejemplifican las múltiples avenidas de la recepción. El epílogo funciona en el proceso de estructuración como bisagra que abre y cierra las posibilidades de comprensión: “A quien ha tenido la paciencia de leerme, ordenadamente hasta este punto, le pregunto: -¿Qué fue lo que hice?” (Gallardo, No te

\footnotetext{
${ }^{12}$ La voz de la narradora deja hablar a Carmela y en otros momentos se establecen diálogos provocando el llamado dialogismo bajtiniano; sin embargo, aquí las voces aparecen múltiples e irónicas y las texturas del discurso devienen paródicas y polifónicas, en el sentido que Bajtin define la polifonía. (Wagy 245).
} 
apresures... 127). Lo autobiográfico y la intertexualidad son los elementos centrales en la narrativa de Gallardo. Los continuos préstamos y asociaciones de tramas de la literatura infantil son retomadas y subvertidas por la autora formando un collage que apunta a identidades e intersubjetividades cambiantes y múltiples en el tiempo y en el espacio escritural. El libro va construyendo un sujeto femenino plural; los estadios en donde se mueven sus personajes son fantásticos y oníricos, dentro de otros espacios discursivos; han sido extraídos de cuentos infantiles, anécdotas, cine y teatro infantil, y se han ido formando fragmentariamente. Y es que el sujeto autobiográfico femenino es regularmente descentrado, múltiple, marginal y en continuo movimiento (Maíz, "Inter(subjetividad)...” 99). Eugenia Gallardo contribuye de manera original en este renglón revelando "la conciencia del papel de la diferencia sexual en la construcción de la subjetividad e identidad de los personajes femeninos" (Lagos 124).

A manera de cierre podría decir que las texturas feministas de las obras de estas escritoras tienen parentezco: lo tortuoso y edípico de la novela de Diamela Eltit está siendo retrabajado de forma paródica y humorística por Gallardo, cuyos toques melodramáticos desarman el patetismo contenido en el destino femenino de los personajes simbolizados en los cuentos clásicos para niños. Al igual que A hora da estrela y Los vigilantes, No te apresures en llegar a la torre de Londres resulta un texto fragmentado, híbrido, desconstructivo, en donde se reproblematizan los asuntos de género desde una visión mucho más escéptica que en las generaciones precedentes, emplazando las formas de conducta de los personajes dentro del esquema social machista, pero sin la pulsión visceral de Eltit y más cercana al ludismo lispectoriano. Al mismo tiempo, en su afán de parodiar la autobiografía tradicional, la obra se convierte en una serie de interrogantes para descifrar, bastante cerca ideológicamente de las intenciones de la autora de Los vigilantes. Otro de los rasgos de enlace entre las estéticas de Eltit y Gallardo vienen a ser los espacios de la textualidad: sus personajes femeninos se mueven en espacios cerrados que en Eltit se ubican en ciudades asediadas por el miedo, en tanto en Gallardo se trata de escapar de las jaulas intemporales de los cuentos de hadas al desconstruirlos y resemantizarlos (si no, se descubrirá eventualmente que la torre de Londres no es el reloj supuestamente simbólico de la historia y la democracia, sino la cárcel donde todo sueño se acaba...).

\section{Bibliografía}

Andrade, Mario de. Macunaíma o heroi sem senhum carater. São Paulo: Oficinas Gráficas de E. Cupalo, 1928.

Arêas,Vilma. "Un poco de sangre observaciones sobre A hora da estrela de Clarice Lispector”. Escritura 14/28 (julio-diciembre 1989): 403-15.

Asturias, Miguel Ángel. Leyendas de Guatemala. Madrid: Oriente, 1930.

Beverley, John y Hubo Achugar. La voz del otro: testimonio, subalternidad y verdad narrativa. Lima-Pittsburgh: Latinoamericana Editores, 1992.

Brunner, José Joaquín. “Vida cotidiana, sociedad y cultura”. FLACSO 151 (Santiago de Chile, 1973-82): 69.

Carpentier, Alejo. Écue-yamba-O. Historia afro-cubana. Madrid: Editorial España, 1933. 
Eltit, Diamela. Los vigilantes. Santiago de Chile: Editorial Sudamericana, 1994. Lumpérica. Santiago de Chile: Ediciones del Ornitorrinco, 1983. El cuarto mundo. Santiago de Chile: Planeta, 1988. y Paz Errazuriz. El infarto del alma. Santiago de Chile: Francisco Zegers Editor, 1994.

Ferreira Pinto, Cristina.O bildungsroman femenino: quatro exemplos brasileiros. São Paulo: Editora Perspectiva, 1990.

Friedman, Edward. "Delimitando marcos literarios: la pícara y los problemas del género". Modalidades de representación del sujeto auto/bio/gráfico femenino. Magdalena Maíz y Luis Peña, eds. México: Facultad de Filosofía y Letras, 1997.

Gallardo, Eugenia. No te apresures en llegar a la Torre de Londres, porque la Torre D Londres, no es el Big Ben. Guatemala: F\&G Editores, 1999. Carta para Aida Toledo. 21 Marzo 2000.

Gallegos, Rómulo. Doña Bárbara. [1931] New York: Peter Smith, 1948.

García Escobar, Carlos René. “La narrativa guatemalteca escrita por mujeres”. La hora (Guatemala 18 Junio 1990): N. pag.

Güiraldes, Ricardo. Don Segundo Sombra. New York: H. Holt, 1945.

Helena, Lucia. Nem musa, nem medusa: itinerários da escrita em Clarice Lispector. Niterói: EDUFF, 1997.

Hirsch, Mariana.

Lagos, María Inés. En tono mayor. Santiago de Chile: Cuarto Propio, 1996.

Lértora, Juan Carlos.Una poética de literatura menor: la narrativa de Diamela Eltit. Santiago de Chile: Editorial Cuarto Propio, 1993.

Lispector, Clarice. A hora da estrela. Rio de Janeiro: Francisco Alves Editora, 1990.

Maiz, Magdalena y Luis Peña. Modalidades de representación del sujeto auto/bio/gráfico femenino. México: Facultad de Filosofía y Letras, 1997.

Malcuzynski, Pierrette. Sociocríticas/prácticas textuales/culturas de fronteras. Amsterdam: Editions Rodopi, 1991.

Méndez de Penedo, Lucrecia. "La inquietante inocencia en la narrativa de Eugenia Gallardo”. Texto de la presentación del libro No te apresures en llegar a la Torre de Londres porque la Torre D Londres no es el Big Ben de Eugenia Gallardo. La Ermita 5/19 (julio-septiembre 2000): 27-33.

Molloy, Sylvia. Acto de presencia. México: Fondo de Cultura Económica, 1991.

Morales, Leonidas. Conversaciones con Diamela Eltit. Santiago de Chile: Editorial Cuarto Propio, 1999.

Nagy, Silvia. "Palabras cruzadas: dialoguismo e intertextualidad en 'Querido Diego' de Elena Poniatovska”. Modalidades de representación del sujeto auto/bio/gráfico femenino. Magdalena Maiz y Luis Peña, eds. México: Facultad de Filosofía y Letras, 1997. 243-54.

Olea, Raquel. "El cuerpo-mujer. Un recorte de lectura en la narrativa de Diamela Eltit”. Una poética de literatura menor: la narrativa de Diamela Eltit. Juan Carlos Lértora, ed. Santiago de Chile: Editorial Cuarto Propio, 1993. 
Ortega, Julio. “Diamela Eltit y el imaginario de la virtualidad”.Una poética de literatura menor: la narrariva de Diamela Eltit. Juan Carlos Lértora, ed. Santiago de Chile: Editorial Cuarto Propio, 1993.

Pastor, Beatriz. "Polémicas en torno al canon: implicaciones filosóficas, pedagógicas y políticas”. Casa de las Américas 29/17 (1988): 78-87.

Pfeiffer, Erna. Exiliadas, emigrantes, viajeras: encuentros con diez escritoras latinoamericanas. Madrid: Iberoamericana, 1995.

Richard, Nelly “Tres funciones de escritura: desconstrucción, simulación, hibridación”. Una poética de literatura menor: la narrativa de Diamela Eltit. Juan Carlos Lértora, ed. Santiago de Chile: Editorial Cuarto Propio, 1993.

Rivera, José Eustasio. La vorágine. Buenos Aires/México: Espasa-Calpe Argentina, 1939.

Schroeder, Regina. “Introducción”. Pezóculos. Aida Toledo, ed. Guatemala: Palo de Hormigo, 2001. 11-17.

Sklodowska, Elzbieta. La parodia en la nueva novela hispanoamericana (1960-1985). Amsterdam-Philadelphia: John Benjamins, 1991.

Tafra, Silvia. Diamela Eltit: El rito de pasaje como estrategia textual. Santiago de Chile: RiL Editores, 1998. 